\title{
Glacier Velocity Changes in the Himalayas in Relation to Ice Mass Balance
}

\author{
Yu Zhou ${ }^{1}$, Jianlong Chen ${ }^{1,2}$ and Xiao Cheng ${ }^{3, *(D)}$ \\ 1 Southern Marine Science and Engineering Guangdong Laboratory (Zhuhai), School of Earth Sciences and \\ Engineering, Sun Yat-sen University, Zhuhai 519000, China; zhouyu36@mail.sysu.edu.cn (Y.Z.); \\ chenjlong25@mail2.sysu.edu.cn (J.C.) \\ 2 Guangdong Geological Survey Institute, Guangzhou 510062, China \\ 3 Southern Marine Science and Engineering Guangdong Laboratory (Zhuhai), School of Geospatial \\ Engineering and Science, Sun Yat-sen University, Zhuhai 519000, China \\ * Correspondence: chengxiao9@mail.sysu.edu.cn
}

Citation: Zhou, Y.; Chen, J.;

Cheng, X. Glacier Velocity Changes in the Himalayas in Relation to Ice Mass Balance. Remote Sens. 2021, 13, 3825. https://doi.org/10.3390/rs13193825

Academic Editors: Yi Luo and Gareth Rees

Received: 20 August 2021

Accepted: 22 September 2021

Published: 24 September 2021

Publisher's Note: MDPI stays neutral with regard to jurisdictional claims in published maps and institutional affiliations.

Copyright: (c) 2021 by the authors. Licensee MDPI, Basel, Switzerland. This article is an open access article distributed under the terms and conditions of the Creative Commons Attribution (CC BY) license (https:// creativecommons.org/licenses/by/ $4.0 /)$.

\begin{abstract}
Glacier evolution with time provides important information about climate variability. Here, we investigated glacier velocity changes in the Himalayas and analysed the patterns of glacier flow. We collected 220 scenes of Landsat-7 panchromatic images between 1999 and 2000, and Sentinel-2 panchromatic images between 2017 and 2018, to calculate surface velocities of 36,722 glaciers during these two periods. We then derived velocity changes between 1999 and 2018 for the early winter period, based on which we performed a detailed analysis of motion of each individual glacier, and noted that the changes are spatially heterogeneous. Of all the glaciers, 32\% have sped up, $24.5 \%$ have slowed down, and the rest $43.5 \%$ have remained stable. The amplitude of glacier slowdown, as a result of glacier mass loss, is significantly larger than that of speedup. At regional scales, we found that glacier surface velocity in winter has uniformly decreased in the western part of the Himalayas between 1999 and 2018, while increased in the eastern part; this contrasting difference may be associated with decadal changes in accumulation and/or melting under different climatic regimes. We also found that the overall trend of surface velocity exhibits seasonal variability: summer velocity changes are positively correlated with mass loss, i.e., velocity increases with increasing mass loss, whereas winter velocity changes show a negative correlation. Our study suggests that glacier velocity changes in the Himalayas are spatially and temporally heterogeneous, in agreement with studies that previously highlighted this trend, emphasising complex interactions between glacier dynamics and environmental forcing.
\end{abstract}

Keywords: glacier velocity changes; Himalayas; Landsat-7; Sentinel-2; ice mass balance

\section{Introduction}

Glaciers are sensitive to climate variability and are a major contributor to global sea level rise [1-7]. It is of great importance to understand glacier evolution with time because it provides direct evidence for climate change [2,8,9]. The Himalayas host the largest volume of glaciers outside the polar regions, which also contribute importantly to water resources for the Indus and Ganges basins [10-12]. Due to the difficult accessibility of high mountain areas, remote sensing has been a powerful tool for studying the Himalayan glaciers. Researchers have used satellite altimetry (e.g., $[2,13,14])$ and optical satellite stereo imagery (e.g., $[7,15,16])$ to quantify glacier mass balance in the Himalayas. Although the estimates derived from different techniques vary, they consistently show that the Himalayan glaciers are experiencing significant thinning and mass loss, thereby affecting ice fluxes and river discharge. The thinning rate is also suggested to have accelerated in the past 40 years, which is possibly driven by atmospheric warming and associated energy fluxes [15-17]. Recently, Dehecq et al. [9] investigated the response of glacier flow to mass changes at regional scales. They estimated time-series glacier velocities from 2000 to 2016, 
using Landsat-7 optical satellite images [18], and found that the variability in velocity changes within a large region can be explained solely by changes in ice thickness, i.e., ice mass balance [9]. Their study provides a novel way for estimating ice mass balance in the Himalayas as glacier velocity changes can be easily measured with satellite images.

Glacier surface velocity in summer has been heavily exploited, e.g., $[9,18]$. Velocity estimates in [9] show that glaciers in the Himalayas have experienced significant slowdown in the past two decades. However, seasonal variability of regional glacier motion remains unclear. The aim of this study is to explore the long-term winter velocity and its changes. We first derived glacier velocities for two periods, early winter in 1999-2000 and 2017-2018, using Landsat-7 and Sentinel-2 image pairs, respectively. High-resolution satellites provide a powerful tool for monitoring ice and snow $[19,20]$. We chose Sentinel-2 over Landsat7 for mapping the present glacier motion because it has been tested to have a better geometric and radiometric quality [21]. By differencing the Landsat-7 and Sentinel-2 derived velocities, we map velocity changes over nearly two decades, and, combining the data with glacier mass balance, we show the complex patterns of glacier flow in the Himalayas.

\section{Study Area}

The Himalaya front (Figure 1) stretches over $3000 \mathrm{~km}$ from the west to the east, containing more than 36,000 glaciers of different sizes (Randolph Glacier Inventory, RGI 6.0). The topography increases rapidly across the front, from $200 \mathrm{~m}$ in the south to over $5000 \mathrm{~m}$ in the north, entering the Tibetan Plateau. Evolution of glaciers in different parts of the Himalayas is affected by different climatic regimes. In the western part, snow accumulation is controlled by westerly atmospheric circulations, so Hindu Kush, Spiti Lahaul and Karakoram receive most accumulation during winter. In the eastern part, the Indian summer monsoon dominates the accumulation in West Nepal, East Nepal, Bhutan and Nyainqentanglha [2,12,22-24]. The extreme topography creates additional complexity; precipitation at high-altitude regions has been suggested to be 2-10 times higher than that at low-altitude regions $[25,26]$. As a result, glaciers in the Himalayan front exhibit contrasting variabilities in evolution and mass balance $[2,7,9]$. Shaded relief of the Himalaya region generated from the 3 arc second Shuttle Radar Topography Mission (SRTM) DEM [27] is shown in Figure 1.

\section{Data and Methods}

In this study, we focused primarily on surface velocity changes of the Himalayan glaciers at decadal scales. Satellite optical images were used to generate glacier velocity maps at different times. We collected 40 pairs of Landsat-7 Level-1T data between 1999 and 2000 to calculate glacier velocity during this period. Each panchromatic Landsat-7 Level-1T image covers an area of $185 \mathrm{~km} \times 170 \mathrm{~km}$, with a spatial resolution of $15 \mathrm{~m}$. A total of 70 panchromatic Sentinel-2A/B Level-1C image pairs were obtained to calculate glacier velocity between 2017 and 2018. Each Sentinel-2 Level-1C image has a footprint of $100 \mathrm{~km} \times 100 \mathrm{~km}$ and a spatial resolution of $10 \mathrm{~m}$. Dehecq et al. [9] analysed velocity changes in summer. We are interested to explore whether glacier velocities exhibit seasonal variations, so all the 110 pairs of Landsat-7 and Sentinel-2 images used in this study were acquired during winter, centred around December. We also collected glacier geometry data including length, area, slope and thickness from RGI 6.0 and [28], along with satellitederived glacier elevation changes from [7], for a comprehensive analysis of glacier velocity changes and the possible driving factors.

We estimated glacier velocities by applying cross-correlation using the COSI-Corr software package. Optical correlation is implemented in the frequency domain with an accuracy $\sim 1 / 10$ of the input pixel size $[29,30]$. We used a correlation window of 64 pixels $\times 64$ pixels as a first step, followed by 32 pixels $\times 32$ pixels for a second run, with a step of 16 pixels $\times 16$ pixels $(160 \mathrm{~m})$ for Sentinel-2A/B data and 10 pixels $\times 10$ pixels $(150 \mathrm{~m})$ for Landsat-7 data. The resulting east-west and north-south components of the 
displacement were filtered using the non-local means algorithm [30]. The purpose of filtering is to use the correlation to excluded snow-covered regions where the correlation is relatively low. We then used RGI 6.0 to mask out the non-glacial areas and generated two annual velocity fields for 1999-2000 and 2017-2018, for all the 36,722 glaciers within the Himalayas, as shown in Figure 2.

The velocity uncertainty was estimated from the overlapping areas between adjacent pairs. As shown in Figure 3, the Landsat-7 and Sentinel-2 derived velocities have a measurement error of $-3.4 \pm 11.6 \mathrm{~m} \mathrm{yr}^{-1}$ and $0.4 \pm 4.6 \mathrm{~m} \mathrm{yr}^{-1}$, respectively. Since all the image pairs are centred around December with little interannual fluctuations, the uncertainty depends largely on radiometric quality and image resolution, indicating that Sentinel-2 imagery has a better radiometric quality than Landsat-7 imagery [21], and higher resolution improves pixel matching [20], hence yielding more consistent results.

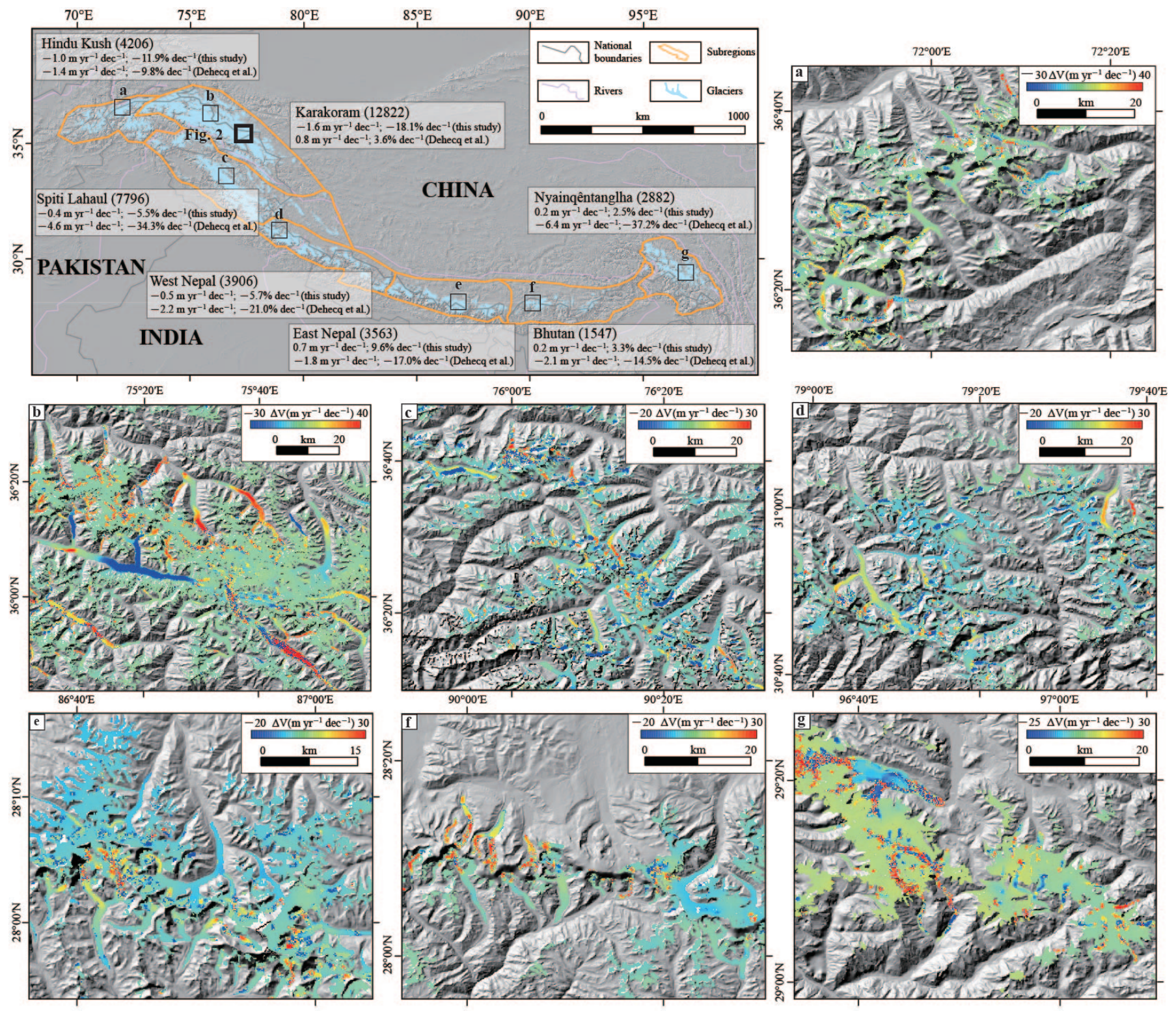

Figure 1. Glaciers are highlighted in light blue. The total number of glaciers in each subregion is labelled. Black box marks the location of Figure 2. We calculated the mean value of velocity changes of each subregion and compared our estimates to [9]. (a-g) shows examples of velocity changes in subregions. See Table 1 for details. 
To calculate velocity changes, we re-sampled the Landsat- 7 and Sentinel-2 derived velocity maps onto the same grid with a spacing of $160 \mathrm{~m}$, and then differenced the two velocities on a pixel basis (Figure 1). Unlike [9], who based their analysis of glacier velocity changes mainly on regions, we conducted our analysis based on individual glacier. For each glacier, we computed its velocity and the associated change by averaging all the pixel values that cover the glacier.

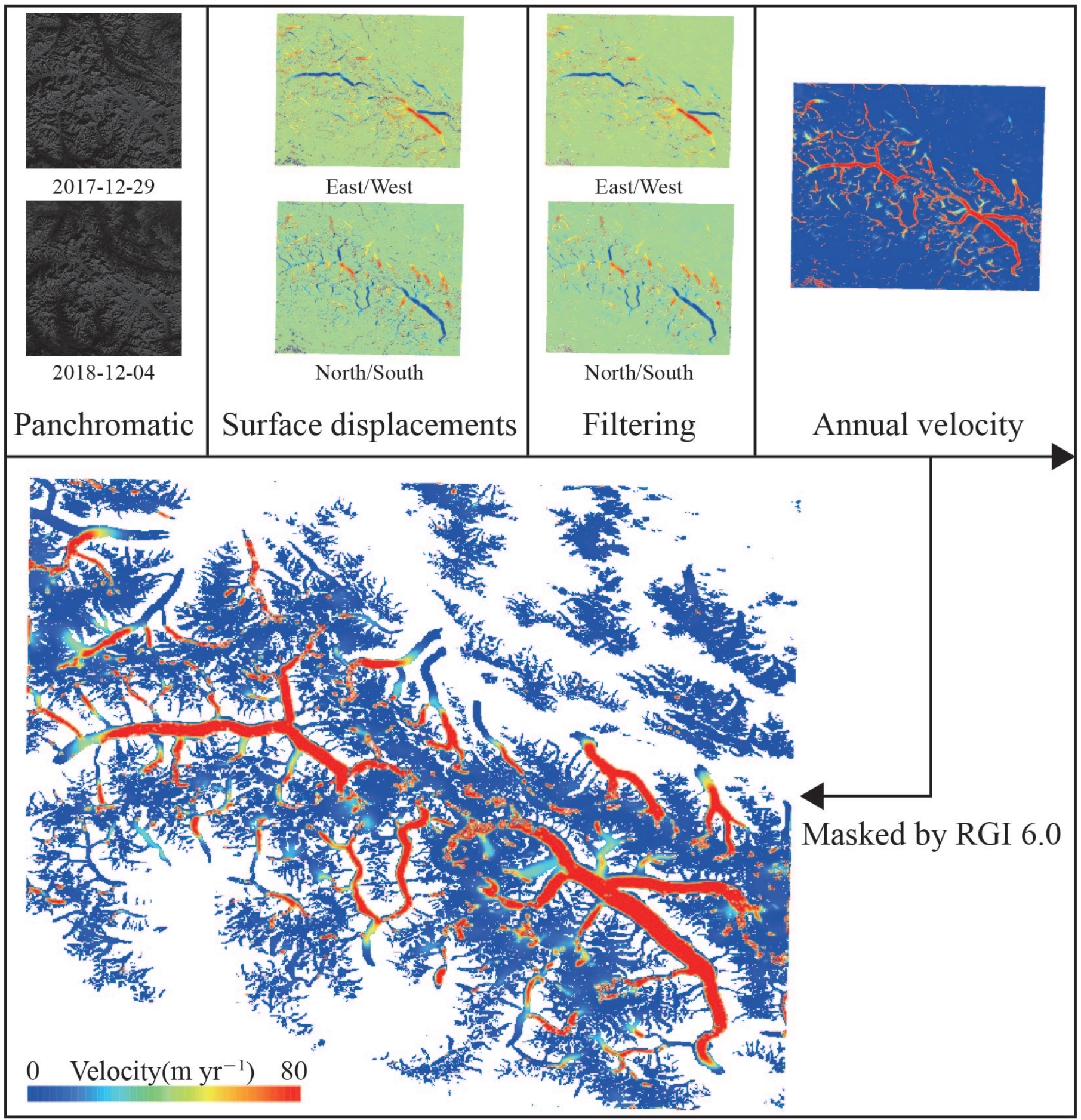

Figure 2. Deriving glacier surface velocity using optical correlation. The Sentinel-2 optical data were provided by the European Space Agency (ESA). See Figure 1 for location. 


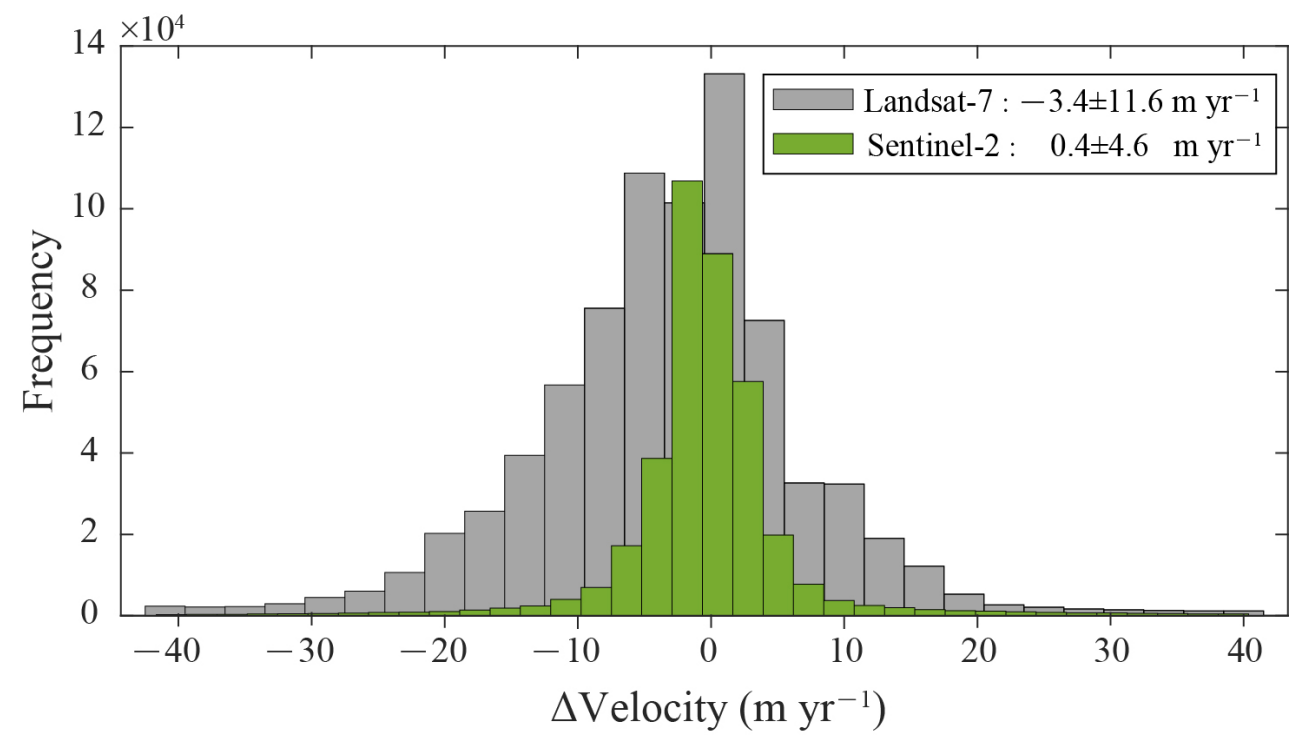

Figure 3. Velocity uncertainties. The Landsat-7 and Sentinel-2 derived velocities have a measurement error of $-3.4 \pm 11.6 \mathrm{~m} \mathrm{yr}^{-1}$ and $0.4 \pm 4.6 \mathrm{~m} \mathrm{yr}^{-1}$, respectively.

\section{Results}

A total of 36,722 glaciers were included in our study (from the RGI 6.0 database). As shown in Table 1, 43.5\% of the glaciers had a stable velocity during 1999-2018 (the difference between Landsat-7 and Sentinel-2 velocities is no more than $\left.3 \mathrm{~m} \mathrm{yr}^{-1}\right), 32.0 \%$ sped up (velocity changes $>3 \mathrm{~m} \mathrm{yr}^{-1}$ ) and $24.5 \%$ slowed down (velocity changes $<-3 \mathrm{~m} \mathrm{yr}^{-1}$ ). Although speedup glaciers outnumber slowdown glaciers, the average amplitude of glacier speedup $\left(6.3 \mathrm{~m} \mathrm{yr}^{-1}\right)$ is much smaller than slowdown $\left(-12.3 \mathrm{~m} \mathrm{yr}^{-1}\right)$. At regional scale, more glaciers in the east of the Himalayas, i.e., West Nepal (33.4\%), East Nepal (56.2\%), Bhutan (34.1\%) and Nyainqentanglha (41.3\%), have experienced speedup than the west in Hindu Kush (22.6\%), Spiti Lahaul (19.6\%) and Karakoram (17.3\%). Karakoram has seen the largest proportion of glacier slowdown (31.5\%), followed by West Nepal (29.1\%), Hindu Kush (28.3\%), Bhutan (22.1\%), Nyainqentanglha (21.9\%), East Nepal (19.6\%) and Spiti Lahaul (18.7\%). The greatest speedup (about $130 \mathrm{~m} \mathrm{yr}^{-1}$ in RGI60-14.04875) and slowdown (about $-250 \mathrm{~m} \mathrm{yr}^{-1}$ in RGI60-14.0300) also occurred in Karakoram.

We analysed glacier surface velocity in combination with glacier geometry data including area, length, slope and thickness. We used Sentinel-2 derived velocities in the analysis, given the smaller measurement uncertainties. The results (Figure 4) showed that small glaciers (area $<20 \mathrm{~km}^{2}$ ), regardless of non-surge and surge types, exhibit complex flow velocities, which are poorly correlated with area $(R=0.13$ for non-surge type and $R=0.22$ for surge type), length $(R=0.12$ and $R=0.21)$, slope $(R=-0.08$ and $R=0.02)$ and thickness $\left(R=-0.01\right.$ and $R=0.09$ ). Flow velocities of large (area $\left.\geq 20 \mathrm{~km}^{2}\right)$, non-surge-type glaciers show a positive correlation with both area $(R=0.69)$ and length $(R=0.78)$, i.e., the size of glaciers, suggesting faster motion with increasing sizes, as glacier flow laws would predict. Surge-type glaciers do not show an evident correlation with any of the factors. We also noted that glacier velocities appear to be independent of, or at least not linearly correlated with, both slope and thickness. Similarly, we analysed the relationship between glacier velocity changes and glacier size and thickness. As shown in Figure 4, velocity changes of both non-surge- and surge-type glaciers are completely independent of glacier geometry, indicated by the very low correlation $(R \approx 0)$. 
Table 1. Statistics of glacier velocity changes in the Himalayas. Stable glaciers are defined as the amplitude of differences between Landsat-7 and Sentinel-2 velocities, i.e., velocity changes between 1999 and $2018, \leq 3 \mathrm{~m} \mathrm{yr}^{-1}$. Velocity changes $>3 \mathrm{~m} \mathrm{yr}^{-1}$ are regarded as speedup and $<-3 \mathrm{~m} \mathrm{yr}^{-1}$ as slowdown. The overall changes were calculated by averaging all the glaciers within each subregion, in order to be comparable with the results in [9].

\begin{tabular}{|c|c|c|c|c|c|c|c|c|c|c|}
\hline & \multirow{2}{*}{ Number of Glaciers } & \multirow{2}{*}{ Speedup } & \multirow{2}{*}{ Slowdown } & \multirow{2}{*}{ Stable } & \multicolumn{2}{|c|}{ Speedup $\left(\mathrm{m} \mathrm{yr}^{-1}\right)$} & \multicolumn{2}{|c|}{ Slowdown $\left(\mathrm{m} \mathrm{yr}^{-1}\right)$} & \multicolumn{2}{|c|}{ Overall $\left(\mathrm{m} \mathrm{yr}^{-1} \mathrm{dec}^{-1}\right)$} \\
\hline & & & & & Average & Maximum & Average & Maximum & This Study & [9] \\
\hline Hindu Kush & 4206 & $22.6 \%$ & $28.3 \%$ & $49.1 \%$ & 5.2 & 29.6 (RGI60-14.24088) & -11.5 & -186.0 (RGI60-14.22312) & -1.0 & -1.4 \\
\hline Karakoram & 12,822 & $17.3 \%$ & $31.5 \%$ & $51.2 \%$ & 6.6 & 127.7 (RGI60-14.04875) & -13.7 & -256.7 (RGI60-14.03000) & -1.6 & 0.8 \\
\hline Spiti Lahaul & 7796 & $19.6 \%$ & $18.7 \%$ & $61.7 \%$ & 6.4 & 81.5 (RGI60-14.19261) & -12.1 & -179.0 (RGI60-14.17193) & -0.4 & -4.6 \\
\hline West Nepal & 3906 & $33.4 \%$ & $29.1 \%$ & $37.5 \%$ & 5.5 & 27.2 (RGI60-14.12426) & -9.7 & -51.4 (RGI60-15.05231) & -0.5 & -2.2 \\
\hline East Nepal & 3563 & $56.2 \%$ & $19.6 \%$ & $24.2 \%$ & 6.3 & 55.8 (RGI60-15.09859) & -12.3 & -62.0 (RGI60-15.09861) & 0.7 & -1.8 \\
\hline Bhutan & 1547 & $34.1 \%$ & $22.1 \%$ & $43.8 \%$ & 6.6 & 39.5 (RGI60-15.02102) & -8.5 & -61.3 (RGI60-15.01907) & 0.2 & -2.1 \\
\hline Nyainqentanglha & 2882 & $41.3 \%$ & $21.9 \%$ & $36.8 \%$ & 6.9 & 95.9 (RGI60-15.12714) & -12.4 & -135.6 (RGI60-15.12081) & 0.2 & -6.4 \\
\hline Total & 36,722 & $32.0 \%$ & $24.5 \%$ & $43.5 \%$ & 6.3 & 127.7 (Karakoram) & -12.3 & -256.7 (Karakoram) & -0.3 & l \\
\hline
\end{tabular}
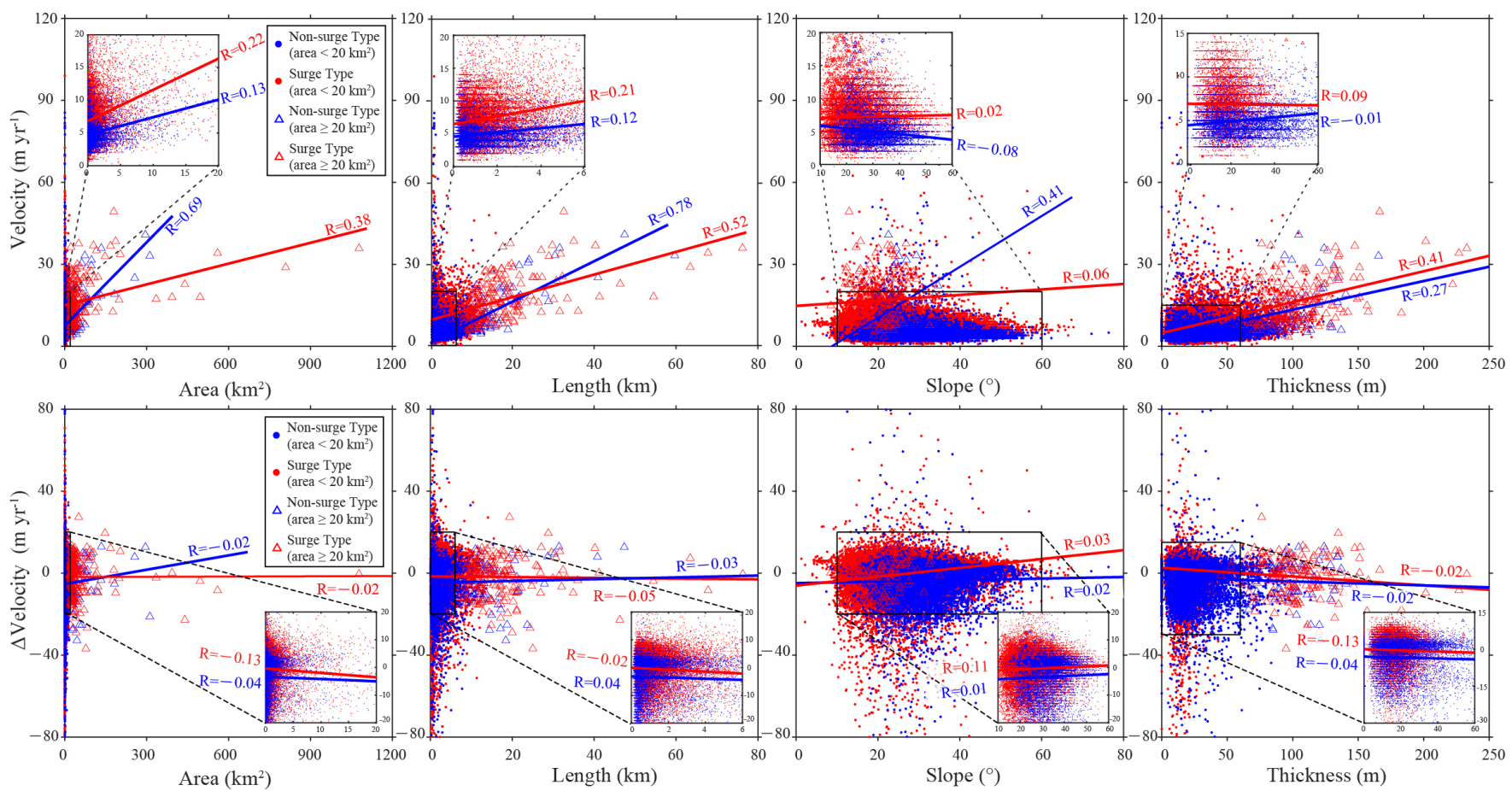

Figure 4. Glacier velocity and velocity changes versus area, length, slope and thickness. Dots and triangles stand for glaciers with an area of smaller than $20 \mathrm{~km}^{2}$ and over $20 \mathrm{~km}^{2}$, respectively. Non-surge- and surge-type glaciers are separated by blue and red. Lines show the linear regression analysis of the corresponding group of data.

\section{Discussion}

\subsection{Regional Patterns of Surface Velocity Changes}

Dehecq et al. [9] calculated time-series velocity anomalies for 11 subregions in the Himalayas. An analysis of glacier changes at regional scales allows us to explore cryospheric responses to climatic forcing. Here, we followed their line of analysis and focused on the 7 subregions that stretch along the range front. In order to compare our estimates to theirs, we averaged the velocity differences of all glaciers in each subregion and calculated the rate of change (velocity differences divided by 1.8 decades). Velocity changes (Table 1) show that, on average, glaciers in Hindu Kush $\left(-1.0 \mathrm{~m} \mathrm{yr}^{-1}\right.$ decade $^{-1}$ for 4206 glaciers), Karakoram (-1.6 $\mathrm{m} \mathrm{yr}^{-1}$ decade $^{-1}$ for 12,822 glaciers), Spiti Lahaul $\left(-0.4 \mathrm{~m} \mathrm{yr}^{-1}\right.$ decade $^{-1}$ for 7796 glaciers) and West Nepal ( $-0.5 \mathrm{~m} \mathrm{yr}^{-1}$ decade $^{-1}$ for 3906 glaciers) have slowed down from 1999 to 2018, whereas a slight acceleration has occurred in the east: East Nepal (0.7 $\mathrm{m} \mathrm{yr}^{-1}$ decade $^{-1}$ for 3563 glaciers), Bhutan $\left(0.2 \mathrm{~m} \mathrm{yr}^{-1}\right.$ decade $^{-1}$ for 1547 glaciers) and Nyainqentanglha ( $0.2 \mathrm{~m} \mathrm{yr}^{-1}$ decade $^{-1}$ for 2882 glaciers). Our results differ from [9]'s, 
who found that all subregions have experienced a slowdown between 2000 and 2017, with a changing rate varying from $-6.4 \mathrm{~m} \mathrm{yr}^{-1}$ decade $^{-1}$ in Nyainqentanglha to $-1.4 \mathrm{~m} \mathrm{yr}^{-1}$ decade $^{-1}$ in Hindu Kush, except for Karakoram, which experienced a small speedup (0.8 $\mathrm{m} \mathrm{yr}^{-1}$ decade $\left.^{-1}\right)$. The inconsistency is likely to be resulted from seasonal changes in glacier flow. The images used in our study were collected in December, so our estimates are velocities during winter, while [9]'s velocity estimates are centred around June. Past studies (e.g., [31-33]) have shown that, during summer, when melting occurs, glaciers flow much faster with stronger temporal and spatial variations. Velocity changes during winter $\left(0 \sim 1 \mathrm{~m} \mathrm{yr}^{-1}\right.$ decade $\left.^{-1}\right)$ are considerably smaller than the changes during summer (1 $6 \mathrm{~m} \mathrm{yr}^{-1}$ decade $^{-1}$ ) (see Figure 1 and Table 1 ), possibly due to strong spatio-temporal variations in melting in the Himalayas. From the winter velocity changes, we also observed a contrasting difference between the western (slowdown) and eastern (speedup) parts of the Himalayan front, indicating heterogeneous changes in accumulation and/or melting under different climatic regimes.

\subsection{Linking Surface Velocity Changes with Glacier Mass Balance}

To further investigate the driving factors of glacier velocity changes, we use the empirical power law relation between glacier surface velocity $V$ and driving stress $\tau$ [34-37]:

$$
V=A \tau^{m}
$$

where $A$ and $m$ are positive constants, related to ice rheology, bed topography and flow mechanisms (ice deformation and basal sliding) [34,35]. $m$ has been estimated to vary from 1 (flow over soft sediments, [38]) to 4 (high subglacial pressure, [9]) under different circumstances.

Taking the derivative of $V$ with respect to $\tau$, we have:

$$
d V=A m \tau^{(m-1)} d \tau
$$

Combining Equations (1) and (2), we have:

$$
\frac{d V}{V}=m \frac{d \tau}{\tau}
$$

Assuming that changes in the driving stress $(d \tau)$ are induced by mass balance $(d M)$ and ignoring other factors, as proposed by [9], i.e., $d \tau=C_{1} d M+C_{2}$, we have:

$$
\frac{d V}{V}=\frac{m}{\tau} C_{1} d M+\frac{m}{\tau} C_{2}
$$

where $C_{1}$ and $C_{2}$ are assumed constant, relating the driving stress and mass balance. Dehecq et al. [9] analysed velocity changes and mass balance data and found that, at regional scales, summer velocity changes are positively correlated with mass balance: $\frac{d V}{V} \sim 1.25 d M$ (see Figure 5).

To test whether velocity changes exhibit any seasonal variability, we applied Equation (4) to analyse the winter velocity estimates. We calculated the average values of velocity $V$ and its change $d V$ for each of the glaciers, based on which we determined the overall $d V$ and $V$ for each subregion. The measurements of glacier mass balance $(d M)$ were taken from [7]. Although estimates of glacier mass balance in Brun et al. [7] did not take seasonal variability into account, an earlier study in [2] has shown that the long-term trend of $d M$ is consistent between seasons (the amplitude differs slightly). Therefore, using the average long-term trend of $d M$ should not affect the linear relationship between $d V$ and $d M$. As shown in Figure 5, glacier velocity changes $\frac{d V}{V}$ are negatively correlated with mass balance $\left(\frac{d V}{V} \sim-0.96 d M\right)$, suggesting that ice mass loss promotes glacier motion in winter. This is in contrasting difference with summer velocity changes in the study by [9], which states that mass loss drives glacier slowdown. Such seasonal variability indicates 
different mechanisms of glacier mass loss in the Himalayas. Increased melt conditions in the early winter period, November and December, could enhance velocity, as noted by Bocchiola et al. [39], Pelto et al. [40] in the eastern Himalaya. During summer, mass losses are more likely to be resulted from increased ablation zone melting, given that precipitation has not been significant [41,42]. The result suggests that velocity changes in the Himalayas are temperature driven, rather than accumulation process driven.

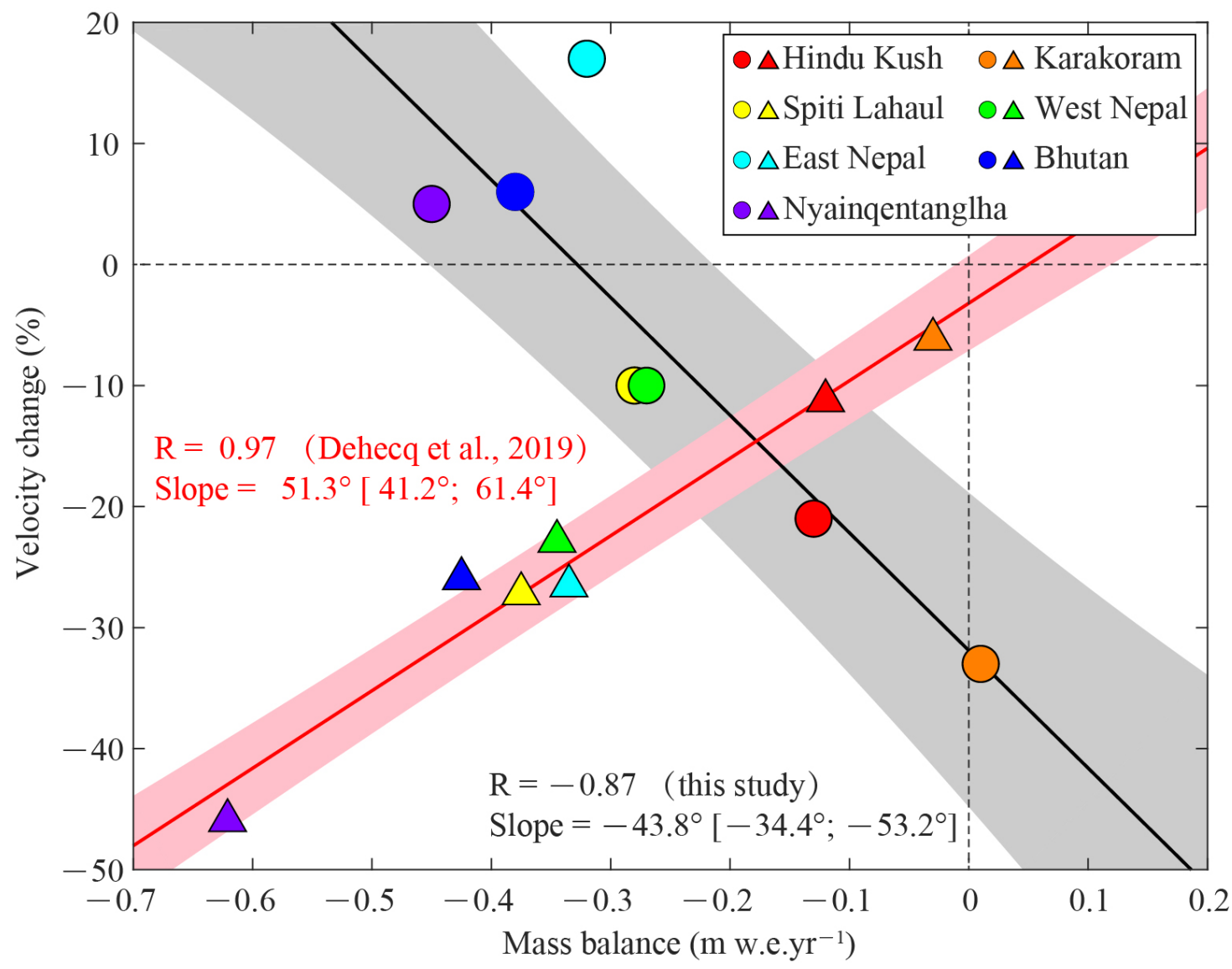

Figure 5. Glacier surface velocity changes versus mass balance. Mass balance data were taken from [7]. Shaded bands indicate $68 \%$ confidence interval. Winter velocity changes (filled circles, in this study) are negatively correlated with mass balance, with a correlation of $R=-0.87$. Summer velocity changes (filled triangles, [9]) are positively correlated with mass balance.

\section{Conclusions}

In this study, we used Landsat-7 and Sentinel-2 optical imagery to investigate glacier surface velocity and the associated changes in the Himalayas. We analysed flow patterns of individual glacier along the Himalayan mountain front and found that glacier velocity changes exhibit an evident heterogeneity at different spatial scales. Of all the 36,722 glaciers, $32 \%$ have experienced speedup, $24.5 \%$ have slowed down, and the rest, $43.5 \%$, have remained stable. At regional scales, the amplitude of velocity changes is significantly larger in summer [9] than that in winter (this study). The decreasing velocities in winter between 1999 and 2018 in the western part of the Himalayas, in contrast to the increasing velocities in the eastern part, may be caused by changes in accumulation and/or melting under different climatic regimes. Accelerated flow in Eastern Nepal may be impacted by melting conditions, where more melting has been observed. We also observed that glacier velocity changes in winter are controlled by mass balance, as suggested by [9]; however, unlike summer velocity changes that are positively correlated with mass balance, winter velocity changes show a negative correlation. Our study suggests that glacier velocity changes in the Himalayas are more spatially and temporally heterogeneous than what 
was previously thought, emphasising complex interactions between glacier dynamics and environmental forcing.

Author Contributions: Y.Z. and J.C. performed data processing and interpreted the results. Y.Z. wrote the original draft. J.C. and X.C. reviewed the paper. All authors have read and agreed to the published version of the manuscript.

Funding: The APC was funded by the Second Tibetan Scientific Expedition and Research Program (STEP) (2019QZKK0901).

Data Availability Statement: Landsat-7 images were downloaded from https: / / earthexplorer.usgs. gov / (accessed on 23 January 2020); Sentinel-2 images were downloaded from https: / / scihub.esa.int/ (accessed on 23 January 2020). The RANDOLPH GLACIER INVENTORY (RGI 6.0) is freely available from https: / / www.gtn-g.ch/data_catalogue_rgi/ (accessed on 23 January 2020).

Acknowledgments: This work was supported by the Second Tibetan Plateau Scientific Expedition and Research Program (STEP) (2019QZKK0901) and Innovatiom Group Project of Southern Marine Science and Engineering Guangdong Laboratory (Zhuhai) (No. 311021008).

Conflicts of Interest: The authors declare that they have no known competing financial interests or personal relationships that could have appeared to influence the work reported in this paper.

\section{References}

1. Kaser, G.; Großhauser, M.; Marzeion, B. Contribution potential of glaciers to water availability in different climate regimes. Proc. Natl. Acad. Sci. USA 2010, 107, 20223-20227. [CrossRef] [PubMed]

2. Kääb, A.; Berthier, E.; Nuth, C.; Gardelle, J.; Arnaud, Y. Contrasting patterns of early twenty-first-century glacier mass change in the Himalayas. Nature 2012, 488, 495-498. [CrossRef] [PubMed]

3. Bolch, T.; Kulkarni, A.; Kääb, A.; Huggel, C.; Paul, F.; Cogley, J.G.; Frey, H.; Kargel, J.S.; Fujita, K.; Scheel, M.; et al. The state and fate of Himalayan glaciers. Science 2012, 336, 310-314. [CrossRef] [PubMed]

4. Yao, T.; Thompson, L.; Yang, W.; Yu, W.; Gao, Y.; Guo, X.; Yang, X.; Duan, K.; Zhao, H.; Xu, B.; et al. Different glacier status with atmospheric circulations in Tibetan Plateau and surroundings. Nat. Clim. Chang. 2012, 2, 663-667. [CrossRef]

5. Kraaijenbrink, P.; Bierkens, M.; Lutz, A.; Immerzeel, W. Impact of a global temperature rise of 1.5 degrees Celsius on Asia's glaciers. Nature 2017, 549, 257-260. [CrossRef] [PubMed]

6. Ren, J.; Jing, Z.; Pu, J.; Qin, X. Glacier variations and climate change in the central Himalaya over the past few decades. Ann. Glaciol. 2006, 43, 218-222. [CrossRef]

7. Brun, F.; Berthier, E.; Wagnon, P.; Kääb, A.; Treichler, D. A spatially resolved estimate of High Mountain Asia glacier mass balances from 2000 to 2016. Nat. Geosci. 2017, 10, 668-673. [CrossRef]

8. Lutz, A.; Immerzeel, W.; Shrestha, A.; Bierkens, M. Consistent increase in High Asia's runoff due to increasing glacier melt and precipitation. Nat. Clim. Chang. 2014, 4, 587-592. [CrossRef]

9. Dehecq, A.; Gourmelen, N.; Gardner, A.S.; Brun, F.; Goldberg, D.; Nienow, P.W.; Berthier, E.; Vincent, C.; Wagnon, P.; Trouvé, E. Twenty-first century glacier slowdown driven by mass loss in High Mountain Asia. Nat. Geosci. 2019, 12, 22-27. [CrossRef]

10. Immerzeel, W.W.; Droogers, P.; De Jong, S.; Bierkens, M. Large-scale monitoring of snow cover and runoff simulation in Himalayan river basins using remote sensing. Remote Sens. Environ. 2009, 113, 40-49. [CrossRef]

11. Guo, W.; Liu, S.; Xu, J.; Wu, L.; Shangguan, D.; Yao, X.; Wei, J.; Bao, W.; Yu, P.; Liu, Q.; et al. The second Chinese glacier inventory: Data, methods and results. J. Glaciol. 2015, 61, 357-372. [CrossRef]

12. Bookhagen, B.; Burbank, D.W. Toward a complete Himalayan hydrological budget: Spatiotemporal distribution of snowmelt and rainfall and their impact on river discharge. J. Geophys. Res. Earth Surf. 2010, 115. [CrossRef]

13. Neckel, N.; Kropáček, J.; Bolch, T.; Hochschild, V. Glacier mass changes on the Tibetan Plateau 2003-2009 derived from ICESat laser altimetry measurements. Environ. Res. Lett. 2014, 9, 014009. [CrossRef]

14. Kääb, A.; Treichler, D.; Nuth, C.; Berthier, E. Brief Communication: Contending estimates of 2003-2008 glacier mass balance over the Pamir-Karakoram-Himalaya. Cryosphere 2015, 9, 557-564. [CrossRef]

15. Maurer, J.; Schaefer, J.; Rupper, S.; Corley, A. Acceleration of ice loss across the Himalayas over the past 40 years. Sci. Adv. 2019, 5, eaav7266. [CrossRef] [PubMed]

16. Ragettli, S.; Bolch, T.; Pellicciotti, F. Heterogeneous glacier thinning patterns over the last 40 years in Langtang Himal, Nepal. Cryosphere 2016, 10, 2075-2097. [CrossRef]

17. Zhou, Y.; Li, Z.; Li, J.; Zhao, R.; Ding, X. Glacier mass balance in the Qinghai-Tibet Plateau and its surroundings from the mid-1970s to 2000 based on Hexagon KH-9 and SRTM DEMs. Remote Sens. Environ. 2018, 210, 96-112. [CrossRef]

18. Dehecq, A.; Gourmelen, N.; Trouvé, E. Deriving large-scale glacier velocities from a complete satellite archive: Application to the Pamir-Karakoram-Himalaya. Remote Sens. Environ. 2015, 162, 55-66. [CrossRef] 
19. Shugar, D.; Jacquemart, M.; Shean, D.; Bhushan, S.; Upadhyay, K.; Sattar, A.; Schwanghart, W.; McBride, S.; de Vries, M.V.W.; Mergili, M.; et al. A massive rock and ice avalanche caused the 2021 disaster at Chamoli, Indian Himalaya. Science 2021, 373, 300-306. [CrossRef] [PubMed]

20. Muhuri, A.; Gascoin, S.; Menzel, L.; Kostadinov, T.; Harpold, A.; Sanmiguel-Vallelado, A.; Moreno, J.I.L. Performance Assessment of Optical Satellite Based Operational Snow Cover Monitoring Algorithms in Forested Landscapes. IEEE J. Sel. Top. Appl. Earth Obs. Remote Sens. 2021, 14, 7159-7178. [CrossRef]

21. Kääb, A.; Winsvold, S.H.; Altena, B.; Nuth, C.; Nagler, T.; Wuite, J. Glacier remote sensing using Sentinel-2. part I: Radiometric and geometric performance, and application to ice velocity. Remote Sens. 2016, 8, 598. [CrossRef]

22. Azam, M.F.; Ramanathan, A.; Wagnon, P.; Vincent, C.; Linda, A.; Berthier, E.; Sharma, P.; Mandal, A.; Angchuk, T.; Singh, V.; et al. Meteorological conditions, seasonal and annual mass balances of Chhota Shigri Glacier, western Himalaya, India. Ann. Glaciol. 2016, 57, 328-338. [CrossRef]

23. Sun, Y.; Jiang, L.; Liu, L.; Sun, Y.; Wang, H. Spatial-temporal characteristics of glacier velocity in the Central Karakoram revealed with 1999-2003 Landsat-7 ETM+ Pan Images. Remote Sens. 2017, 9, 1064. [CrossRef]

24. Fujita, K. Effect of precipitation seasonality on climatic sensitivity of glacier mass balance. Earth Planet. Sci. Lett. 2008, 276, 14-19. [CrossRef]

25. Immerzeel, W.; Wanders, N.; Lutz, A.; Shea, J.; Bierkens, M. Reconciling high-altitude precipitation in the upper Indus basin with glacier mass balances and runoff. Hydrol. Earth Syst. Sci. 2015, 19, 4673-4687. [CrossRef]

26. Dumont, M.; Gascoin, S. Optical remote sensing of snow cover. In Land Surface Remote Sensing in Continental Hydrology; Elsevier: Amsterdam, The Netherlands, 2016; pp. 115-137.

27. Farr, T.G.; Rosen, P.A.; Caro, E.; Crippen, R.; Duren, R.; Hensley, S.; Kobrick, M.; Paller, M.; Rodriguez, E.; Roth, L.; et al. The shuttle radar topography mission. Rev. Geophys. 2007, 45. [CrossRef]

28. Farinotti, D.; Huss, M.; Fürst, J.J.; Landmann, J.; Machguth, H.; Maussion, F.; Pandit, A. A consensus estimate for the ice thickness distribution of all glaciers on Earth. Nat. Geosci. 2019, 12, 168-173. [CrossRef]

29. Leprince, S.; Barbot, S.; Ayoub, F.; Avouac, J.P. Automatic and precise orthorectification, coregistration, and subpixel correlation of satellite images, application to ground deformation measurements. Geosci. Remote Sens. IEEE Trans. 2007, 45, 1529-1558. [CrossRef]

30. Ayoub, F.; Leprince, S.; Keene, L. Users Guide to COSI-CORR Co-Registration of Optically Sensed Images and Correlation; California Institute of Technology: Pasadena, CA, USA, 2009; p. 38.

31. Hooke, R.L.; Calla, P.; Holmlund, P.; Nilsson, M.; Stroeven, A. A 3 year record of seasonal variations in surface velocity, Storglaciären, Sweden. J. Glaciol. 1989, 35, 235-247. [CrossRef]

32. Lemos, A.; Shepherd, A.; McMillan, M.; Hogg, A.E. Seasonal variations in the flow of land-terminating glaciers in Central-West Greenland using Sentinel-1 imagery. Remote Sens. 2018, 10, 1878. [CrossRef]

33. Kraaijenbrink, P.; Meijer, S.W.; Shea, J.M.; Pellicciotti, F.; De Jong, S.M.; Immerzeel, W.W. Seasonal surface velocities of a Himalayan glacier derived by automated correlation of unmanned aerial vehicle imagery. Ann. Glaciol. 2016, 57, 103-113. [CrossRef]

34. Glen, J. Experiments on the deformation of ice. J. Glaciol. 1952, 2, 111-114. [CrossRef]

35. Glen, J.W. The creep of polycrystalline ice. Proc. R. Soc. Lond. Ser. A Math. Phys. Sci. 1955, 228, 519-538.

36. Weertman, J. On the sliding of glaciers. J. Glaciol. 1957, 3, 33-38. [CrossRef]

37. Goldsby, D.; Kohlstedt, D.L. Superplastic deformation of ice: Experimental observations. J. Geophys. Res. Solid Earth 2001, 106, 11017-11030. [CrossRef]

38. MacAyeal, D.R. Large-scale ice flow over a viscous basal sediment: Theory and application to ice stream B, Antarctica. J. Geophys. Res. Solid Earth 1989, 94, 4071-4087. [CrossRef]

39. Bocchiola, D.; Bombelli, G.M.; Camin, F.; Ossi, P.M. Field Study of Mass Balance, and Hydrology of the West Khangri Nup Glacier (Khumbu, Everest). Water 2020, 12, 433. [CrossRef]

40. Pelto, M.; Panday, P.; Matthews, T.; Maurer, J.; Perry, L.B. Observations of Winter Ablation on Glaciers in the Mount Everest Region in 2020-2021. Remote Sens. 2021, 13, 2692. [CrossRef]

41. Wagnon, P.; Vincent, C.; Arnaud, Y.; Berthier, E.; Vuillermoz, E.; Gruber, S.; Ménégoz, M.; Gilbert, A.; Dumont, M.; Shea, J.; et al. Seasonal and annual mass balances of Mera and Pokalde glaciers (Nepal Himalaya) since 2007. Cryosphere 2013, 7, 1769-1786. [CrossRef]

42. Wagnon, P.; Brun, F.; Khadka, A.; Berthier, E.; Shrestha, D.; Vincent, C.; Arnaud, Y.; Six, D.; Dehecq, A.; Ménégoz, M.; et al. Reanalysing the 2007-19 glaciological mass-balance series of Mera Glacier, Nepal, Central Himalaya, using geodetic mass balance. J. Glaciol. 2021, 67, 117-125. [CrossRef] 